\title{
HŐVEZETÉS JELENSÉGÉT TANULMÁNYOZÓ BERENDEZÉS TERVEZÉSE ÉS KIVITELEZÉSE
}

\section{DESIGN AND IMPLEMENTATION OF A LABORATORY STAND FOR STUDYING HEAT TRANSFER BY CONDUCTION}

\author{
Padrah István, ${ }^{1}$ Pásztor Judit, ${ }^{2}$ Farmos Rudolf ${ }^{3}$ \\ Sapientia EMTE, Marosvásárhelyi Kar, Marosvásárhely, Románia \\ ${ }^{1}$ isti207@yahoo.com \\ ${ }^{2}$ pjudit@ms.sapientia.ro \\ 33armos_rudolf@ms.sapientia.ro
}

\begin{abstract}
Thermal conduction is a mechanism of the heat transfer. It is present in our everyday life. The determining of thermal conductivity factor helps us better understanding the heat conduction phenomenon. The goal of this paper is to measure the thermal conductivity factor of different materials and compare it with the values provided by the manufacturers. For achieving this we assemble a measuring station and perform measurements on heat insulating materials.
\end{abstract}

Keywords: heat transfer, thermal conductivity, thermal conductivity factor, heat-insulating material.

\section{Összefoglalás}

A hővezetés a hőterjedés egy egyszerű folyamata, lehetősége. Jelen van mindennapi életünkben, fontos az ismerete. A hővezetési tényező meghatározása segít a hővezetés jelenségének megértésében. A dolgozat célja a különböző anyagok hővezetési tényezőjének mérése és összehasonlítása a gyártók által megadott értékekkel. Ennek érdekében mérőberendezést állítunk össze és méréseket végzünk hőszigetelő anyagokon.

Kulcsszavak: hőterjedés, hővezetés, hővezetési tényező, hőszigetelő anyag.

\section{Bevezetés}

A műszaki képzések hallgatói számára a különböző jelenségek, folyamatok elméleti ismereteinek gyakorlathoz való kötése igen fontos a tananyagok megértése céljából. A szemléltető berendezések műveletek, folyamatok belső összefüggéseinek, törvényszerűségeinek, jellegzetességeinek bemutatására alkalmasak. Egyesítik magukban a konkrét és absztrakt tulajdonságokat. A termikus jelenségek, így a hőterjedés is nagyon elvont folyamatok, ezért szemléltetésük nagyon fontos a leendő műszaki szakemberek számára.

A hő terjedése energiaátadás, ami hőmérsékletkülönbség hatására következik be. A jelenség elemi folyamatai a hővezetés, a hőszállítás és a hősugárzás.

A hővezetés, kondukció, szilárd testekben, nyugalomban lévő folyadékokban és gázokban tapasztalható. A hő terjedése szilárd testekben az atomok rezgése által, rugalmas elemi hullámok révén valósul meg, s ehhez a vezetőkben a szabad elektronok diffúziója is hozzájárul [1]. Folyadékokban és gázokban a molekulák elmozdulása számottevő, itt a hővezetés a rendezetlen termikus mozgásnak köszönhető. Ez utóbbi esetben az ütközések szállítják el az energiát a melegebb oldalról a hidegebb felé [2]. 
Hőszállítás vagy hőáramlás, konvekció, áramló közegben valósul meg. A részecskék egymáshoz képest makroszkopikusan elmozdulnak, és ezzel energiájukat is magukkal szállítják [1].

Hősugárzás, radiáció, esetében nincs közvetítő közeg, az energia elektromágneses hullámok formájában terjed.

A dolgozatban a hővezetés folyamatának jobb megértését elősegítő berendezést valósítunk meg.

A hőterjedés matematikai modelljét Fourier állapította meg, szerinte egy homogén testben a stacionárius hőáram a csökkenő hőmérsékletek irányába mutat, [1]. Fourier-törvény matematikai megfogalmazása:

$$
\dot{q}=-\lambda \cdot \operatorname{grad} T\left[\frac{W}{m^{2}}\right]
$$

ahol: $q$ hőáramsűrüség $\left[\mathrm{W} / \mathrm{m}^{2}\right] ; \lambda$ hővezetési tényező, [W/(m·K)]; $\Delta T$ hőmérséklet különbség, [K].

Egy dimenzióban a hőáram arányos a terjedés irányában tapasztalt hosszegységenkénti hőmérséklet-változással és az erre az irányra merőleges keresztmetszettel:

$$
\dot{Q}=-\lambda \cdot A \cdot \Delta T / \Delta x \quad[W]
$$

ahol: $Q$ hőáram, [W]; $\lambda$ hővezetési tényező, [W/ $(\mathrm{m} \cdot \mathrm{K})] ; A$ keresztmetszet $\left[\mathrm{m}^{2}\right] ; \Delta T$ hőmérséklet különbség, [K]; $\Delta x$ a hideg és a meleg oldal távolsága, [m].

Az (1) és (2) összefüggés csak stacionárius esetre igaz. Emiatt a kísérletek során várni kell arra, hogy a hideg-meleg oldalakon a hőmérséklet állandósuljon.

A hővezetési tényező anyagjellemző, számértéke az anyag szerkezetétől és termodinamikai állapotától függ. Meghatározása bonyolult, erre szakosodott laboratóriumokban végzik. Néhány anyag hővezetési tényezőjét különféle kézikönyvek tartalmazzák, interneten is megtalálhatóak.

Fourier-egyenlet síkfalra vonatkozó egyenlete a következőképpen alakul:

$$
\dot{Q}=-\lambda \cdot A \cdot \frac{t_{2}-t_{1}}{\delta}[W],
$$

ahol: $Q^{*}$ hőáram, [W]; $\lambda$ hővezetési tényező, [W/ $(\mathrm{m} \cdot \mathrm{K})]$; A keresztmetszet $\left[\mathrm{m}^{2}\right]$; $(t 2-t 1)$ a sík fal két oldalán jelentkező hőmérséklet különbség, $\left[{ }^{\circ} \mathrm{C}\right]$; $\delta$ sík fal vastagsága, [m].

A hővezetési tényező számítása:

$$
\lambda=\left|-\frac{\dot{Q}}{A \cdot \frac{t_{2}-t_{1}}{\delta}}\right|\left[\frac{W}{m \cdot K}\right]
$$

A hővezetési tényező függhet a hőmérséklettől. Ezt a függőséget a leggyakrabban az alábbi egyszerüsített összefüggés szerint szokás modellezni [2]:

$$
\lambda=\lambda_{0} \cdot(1+b \cdot t)\left[\frac{W}{m \cdot K}\right]
$$

ahol: $t$ a hőmérséklet, $\left[{ }^{\circ} \mathrm{C}\right] ; \lambda_{0}$ pedig egy referencia hőmérsékleten mért hővezetési tényező, [W/(m·K)].

\section{Mérések és adatfeldolgozás}

\subsection{Mérés elve}

A hővezetési tényező meghatározásához állandósult állapotú mérés abszolút mérés módszerét alkalmazó „Hot Plate” elven működő berendezést készítettünk el, 1. ábra.

A módszer lényege, hogy a vizsgálni kívánt próbatest két oldala között hőmérsékletkülönbséget hoznak létre, aminek a hatására hőáram indul el a melegebb oldal felől a hidegebb oldal irányába. Az egyensúlyi helyzet, az állandósult hőáramlás beállta után a minta hővezetési tényezője egyszerűen számítható a hőáram, a minta vastagsága és a kialakult hőmérsékletkülönbség ismeretében, a (4)-es összefüggés alapján.

\subsection{Mérőberendezés felépítése}

Sík fal hővezetési tényezőjének meghatározásához szükség van egy vezérelhető hőforrásra, amely segítségével a különböző kísérleti feltételek beállíthatók; sík falra, amelyen a mérőeszközök, jelen esetben hőmérséklet szenzorok elhelyezhetőek legyenek; mérőrendszerre, amely a mérést és adatrögzítést megvalósítja. Gondoskodni kell a fal rögzítéséről és falvastagság változtathatóságáról.

A mérés javasolt, hogy egy oktatási tevékenység alatt megtörténjen, vagyis a mérés ideje legyen kevesebb, mint 2 óra.

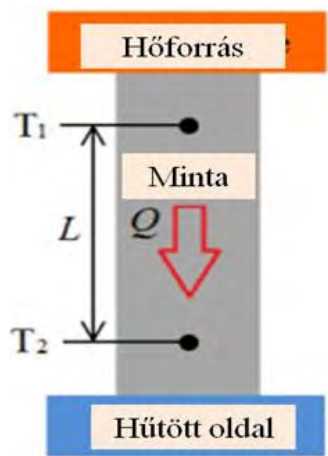

1. ábra. A hővezetési tényező meghatározásának elve [3] 


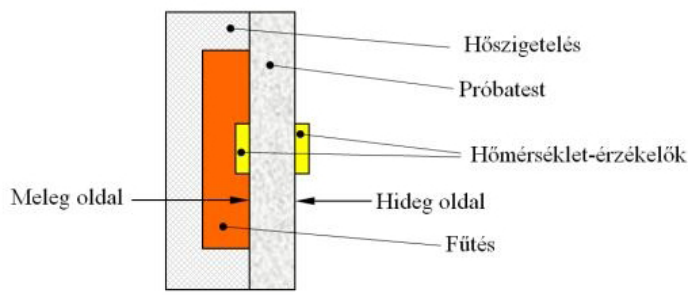

2. ábra. A berendezés elvi vázlata

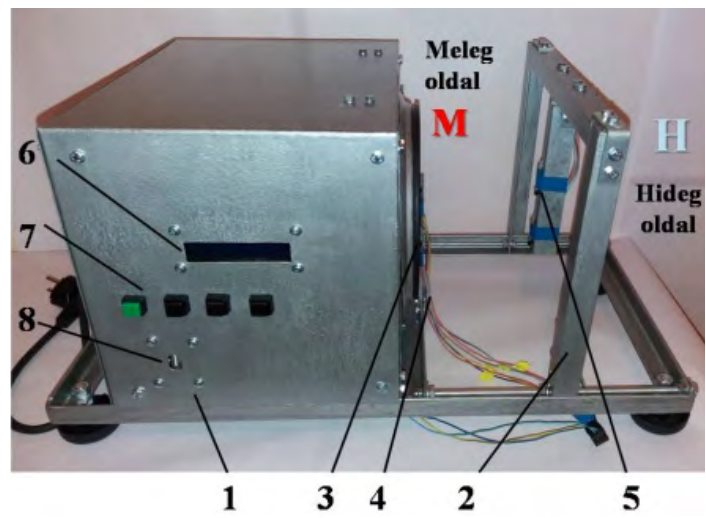

3. ábra. A megvalósitott mérőberendezés

A mérőstand építésének elvi alapja a 2. ábrán követhető.

A tervezett és megépített berendezés a 3 . ábrán látható. Részei: 1-es vezérlő egység: a fütőberendezést kapcsoló relé, Raspberry Pi, mint vezérlő áramkör; 2-es vázszerkezet és a sík fal rögzítésére alkalmas keret, 3-as fütőberendezés, 4-es és 5-ös hőmérséklet szenzorok, 6-os kijelző, 7-es gombok, 8-as adatgyüjtő csatlakozója.

A relé impulzus-szélesség-modulációval (PWM) van vezérelve, ami biztosítja a kívánt hőmérséklet elérését a fütőlapon.

A berendezés a mérés közben teljesen be van borítva hőszigetelő lappal.

\subsection{A mérés menete}

A vizsgálandó polisztirol anyagú sík falat (expandált polisztirol hőszigetelő lapot) a berendezésbe helyezzük. A tartókeretet úgy állítjuk, hogy a szenzorok lehető legközelebb kerüljenek a sík falhoz. A berendezést szigeteljük.

A hálózatra csatlakoztatjuk a berendezést. Indítjuk a főkapcsolót. Az USB memóriát a csatlakozóba helyezzük, majd az indító gombbal indítjuk a mérést.

A fütőlap indításától kezdődően mérjük a hőmérséklet értékeit a sík fal mindkét oldalán, a meleg és hideg oldalon elhelyezett két-két szenzorral.

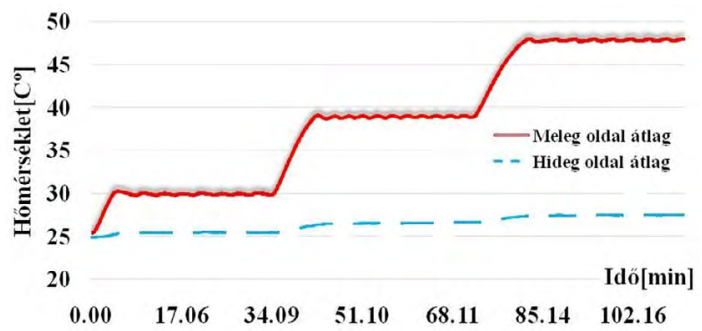

4. ábra. A hideg és meleg oldal hömérsékletváltozása

Az első célhőmérséklet $30^{\circ} \mathrm{C}$. A célhőmérséklet beállása után 30 percig ezt a hőmérsékletet tartja a fütőlap, miközben a szenzorok vételezik az adatokat. A mérési adatok USB memórián tárolódnak.

Ezután ismét fütés következik, a fütőlap felmelegedik a második célhőmérsékletre, $40^{\circ} \mathrm{C}$-ra, majd itt is adatokat gyüjtünk 30 percig, miközben a fütőlap szinten tarja a beállított hőmérsékletet.

A harmadik célhőmérséklet $50^{\circ} \mathrm{C}$, ezért előbb melegítünk, majd szinten tartjuk 30 percig ezt a hőmérsékletet is a fütőlap segítségével. A mérés közben az adatok most is tárolódnak.

A célhőmérsékletek elérése és szinten tartása a kívánt ideig, külső beavatkozás nélkül kell, hogy megtörténjen. A felhasználóként csak az esetleges hibákat felügyeljük. Szükség esetén a vészleállítás is megvalósítható.

\subsection{Az adatok feldolgozása}

$\mathrm{Az}$ adatokat a berendezés 4 másodpercenként rögzíti, menti „.csv” típusú állományba. Az adatokat a 4. ábra jeleníti meg:

A meleg oldalon mért hőmérsékletek középértékei szemléltetik az állandósult szakaszokat és a tervezett hőmérséklet emelkedést. A hideg oldalon is észlehető a hőmérséklet emelkedése, ami a sík fal hővezetését igazolja.

A méréseket elvégeztük $20 \mathrm{~mm}$-es, $50 \mathrm{~mm}$-es és 80 mm-es falvastagságnál. A méréseket háromszor ismételtük. A hővezetési tényezők középértékeit kiszámoltuk az állandósult szakaszokon a (4)-es összefüggés alapján. Az adatokat a 1.táblázatban rögzítettük.

A hővezetési tényezők alakulását az 5.ábrán szemléltetjük.

A hővezetési tényező értéke emelkedik a hőmérséklettel, amint az várható volt.

A hővezetési tényező anyagjellemző, független a fal vastagságától. A berendezéssel a különböző falvastagságokra más-más hővezetési tényező értékeket határoztunk meg. A jelenség a berendezés 
1. táblázat. A mérési adatok középértékei a különböző falvastagságoknál

\begin{tabular}{|c|c|c|c|}
\hline $\boldsymbol{\delta}=\mathbf{2 0} \mathbf{~ m m}$ & $\boldsymbol{\delta}=\mathbf{5 0} \mathbf{~ m m}$ & $\boldsymbol{\delta}=\mathbf{8 0} \mathbf{~ m m}$ & $\begin{array}{c}\text { Mérték- } \\
\text { egység }\end{array}$ \\
\hline $\mathrm{Q}_{30}=1.45$ & $\mathrm{Q}_{30}=1.22$ & $\mathrm{Q}_{30}=1.00$ & {$[\mathrm{~W}]$} \\
\hline $\mathrm{Q}_{40}=4.54$ & $\mathrm{Q}_{40}=4.23$ & $\mathrm{Q}_{40}=4.24$ & {$[\mathrm{~W}]$} \\
\hline $\mathrm{Q}_{50}=7.69$ & $\mathrm{Q}_{50}=7.63$ & $\mathrm{Q}_{50}=8.17$ & {$[\mathrm{~W}]$} \\
\hline$\Delta \mathrm{t}_{30}=4.48$ & $\Delta \mathrm{t}_{30}=4.341$ & $\Delta \mathrm{t}_{30}=4.22$ & {$\left[{ }^{\circ} \mathrm{C}\right]$} \\
\hline$\Delta \mathrm{t}_{40}=12.43$ & $\Delta \mathrm{t}_{40}=13.01$ & $\Delta \mathrm{t}_{40}=13.16$ & {$\left[{ }^{\circ} \mathrm{C}\right]$} \\
\hline$\Delta \mathrm{t}_{50}=20.34$ & $\Delta \mathrm{t}_{50}=21.55$ & $\Delta \mathrm{t}_{50}=21.90$ & {$\left[{ }^{\circ} \mathrm{C}\right]$} \\
\hline$\lambda_{30}=0.19$ & $\lambda_{30}=0.19$ & $\lambda_{30}=0.25$ & {$[\mathrm{~W} /(\mathrm{m} \cdot \mathrm{K})]$} \\
\hline$\lambda_{40}=0.12$ & $\lambda_{40}=0.22$ & $\lambda_{40}=0.34$ & {$[\mathrm{~W} /(\mathrm{m} \cdot \mathrm{K})]$} \\
\hline$\lambda_{50}=0.13$ & $\lambda_{50}=0.24$ & $\lambda_{50}=0.40$ & {$[\mathrm{~W} /(\mathrm{m} \cdot \mathrm{K})]$} \\
\hline
\end{tabular}

szigetelésének hiányosságával magyarázható, de az inhomogén szerkezetű próbatest is okozhatja az eltérést.

Az expandált polisztirol hővezetési tényezőjének referencia-értékeket $20^{\circ} \mathrm{C}$-on határozzák meg. A hővezetési tényező értéke 0,035...0,050 [W/ $(\mathrm{m} \cdot \mathrm{K})]$ között található [4].

Felhasználva a mérési adatok regressziós egyeneseinek egyenletét, kiszámoltuk a hővezetési tényező értékét $20^{\circ} \mathrm{C}$-ra, mindhárom falvastagságnál, majd ennek alapján korrekciós tényezőket határoztunk meg,

$\lambda_{20, \text { berendez és }}=0.007 \cdot t+0.0689\left[\frac{W}{m \cdot K}\right]$

$\lambda_{20, \text { berendez ès }}=0.007 \cdot 20+0.0689=0.0829\left[\frac{\mathrm{W}}{\mathrm{m} \cdot \mathrm{K}}\right]$

$\mathrm{Az}$ intervallum közepéhez, $\lambda 20$, referencia $=0,043[\mathrm{~W} /(\mathrm{m} \cdot \mathrm{K})]$ értékhez számoltuk a korrekciós tényezőt:

$k=\frac{\lambda_{20, \text { referencia }}}{\lambda_{20, \text { berendez és }}}=\frac{0.043}{0.0829}=0.518$

Hasonló számolás alapján határoztuk meg a korrekciós tényezőt $50 \mathrm{~mm}$ és $80 \mathrm{~mm}$ falvastagságnál is, az eredményeket 2 . táblázatban foglaltuk össze.

$\mathrm{Az}$ általunk megvalósított mérőműszer mérési adatai a következőképpen alakulnak, polisztirol esetében:

$$
\lambda=k \cdot \lambda_{20, \text { számolt }}\left[\frac{W}{m \cdot K}\right]
$$

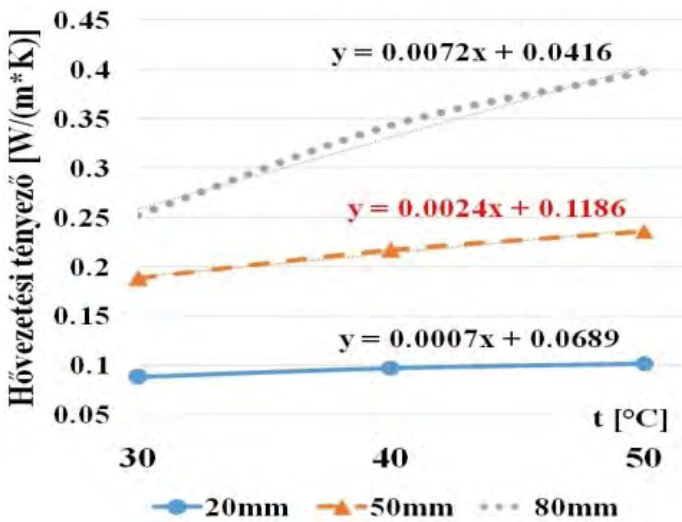

5. ábra. A mért hővezetési tényező változása a hömérséklet függvényében

2. táblázat. A méröberendezés korrekciós tényezői

\begin{tabular}{|c|c|c|c|}
\hline & $\boldsymbol{\delta}=\mathbf{2 0} \mathbf{~ m m}$ & $\boldsymbol{\delta}=\mathbf{5 0} \mathbf{~ m m}$ & $\boldsymbol{\delta}=\mathbf{8 0} \mathbf{~ m m}$ \\
\hline $\begin{array}{c}\lambda_{20, \text { számolt }} \\
{[\mathrm{W} /(\mathrm{m} \cdot \mathrm{K})]}\end{array}$ & 0,0829 & 0,1666 & 0,1856 \\
\hline$k$ & 0,518 & 0,2581 & 0,2316 \\
\hline
\end{tabular}

\section{Következtetések}

A sík fal hővezetési tényezőjének meghatározása segíti a hővezetés jelenségének megértését.

A mérőberendezéssel meghatározott hővezetési tényező értékei eltérnek a gyártók által megadott értékektől. A mérések pontosabbá tétele érdekében javasolt elvégezni a berendezés jobb hőszigetelését és a berendezés hőveszteségének modellezését.

\section{Szakirodalmi hivatkozások}

[1] Bihari P.: 4. Hővezetés és hősugárzás. In: Műszaki hőtan. Edutus Főiskola, Budapest, 2012. https://www.tankonyvtar.hu/hu/tartalom/tamop412A/2010-0017_42_muszaki_hotan/ch04.html (2019.02.10)

[2] Kakucs A.: Müszaki hőtan. Scientia Kiadó, Kolozsvár, 2005. 150-160.

[3] Dongliang Z., Xin Q., Xiaokun G.: Measurement Techniques for Thermal Conductivity and Interfacial Thermal Conductance of Bulk and Thin Film Materials. University of Colorado, Boulder, 2017. 5-10.

h t t p s://arxiv.org/ftp/arxiv/papers/1605/1605.08469.pdf (2018.06.15)

[4] AV Group Hungary, Polisztirol dryvit hőszigetelés http://www.szigeteloanyagarak.hu/polisztirol-hoszigeteles/polisztirol-dryvit-hoszigeteles/ (2018.05.15.). 